\title{
Aquatic biodiversity and saline lakes: Lake Bogoria National Reserve, Kenya
}

\author{
David M. Harper ${ }^{1, *}$, R. Brooks Childress ${ }^{1,2,3}$, Maureen M. Harper ${ }^{1}$, Rosalind R. Boar ${ }^{4}$, Phil \\ Hickley $^{5}$, Suzanne C. Mills ${ }^{6}$, Nickson Otieno ${ }^{3}$, Tony Drane ${ }^{7}$, Ekkehard Vareschi ${ }^{8}$, Oliver \\ Nasirwa $^{2,3}$, Wanjiru E. Mwatha ${ }^{9,10}$, Joanna P.E.C. Darlington ${ }^{11}$ \& Xavier Escuté-Gasulla ${ }^{12}$ \\ ${ }^{1}$ Department of Biology, University of Leicester, Leicester LE1 7RH, U.K.; ${ }^{2}$ Threatened Species, Wildfowl \& \\ Wetland Trust, Slimbridge, Gloucestershire GL2 7BT, U.K.; ${ }^{3}$ Department of Ornithology, National Museums of \\ Kenya, Box 40658, Nairobi, Kenya; ${ }^{4}$ Centre for Ecology, Evolution and Conservation, University of East Anglia, \\ Norwich, U.K.; ${ }^{5}$ Environment Agency, Kidderminster, DY11 7RA, U.K.; ${ }^{6}$ Department of Biological and \\ Environmental Science, University of Jyväskylä, P.O. Box 35 YAC, FIN - 40014, Jyväskylä, Finland; ${ }^{7} 19$ Station \\ Road, Cogenhoe, Northamptonshire, England; ${ }^{8}$ Carl von Ossietzky Universität, P.O.Box 2503, D-26111 \\ Oldenburg, Germany; ${ }^{9}$ Department of Microbiology, University of Leicester, Leicester LE1 7RH, U.K.; ${ }^{10}$ Botany \\ Department, Kenyatta University, P.O. Box 43844-GPO, Nairobi, Kenya; ${ }^{11}$ Department of Zoology, Downing \\ Street, Cambridge, England; ${ }^{12}$ Departament de Biologia, Universitat de Barcelona, Barcelona, Spain. \\ *Author for correspondence: E-maildmh@le.ac.uk
}

Received 26 March 2003; in revised form 2 May 2003; accepted 2 May 2003

Key words: African Rift Valley, spirulina Arthrospira fusiformis, lesser flamingo Phoeniconaias minor, Ramsar, avian tuberculosis

\begin{abstract}
Lake Bogoria, in the Rift Valley of Kenya is an extreme saline lake (conductivity $40-80 \mathrm{mS} \mathrm{cm}^{-1}$, alkalinity $1500 \mathrm{~m} \mathrm{equ}^{-1}$ ). It is hydrologically more stable than the other, endorheic lakes in Kenya, because it is deep maximum depth at present just over $10 \mathrm{~m}$ in an area of $3000 \mathrm{ha}$ - and so does not have periods when it is dry. It is ecologically simple, with only one species dominating the phytoplankton - the cyanobacterium 'spirulina', Arthrospira fusiformis. Its biomass and productivity were very high - biomass between 38 and $365 \mu \mathrm{g} 1^{-1}$

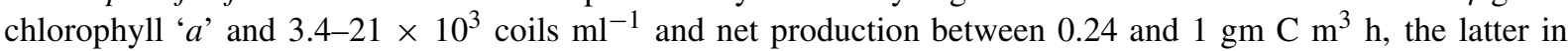
a narrow zone of less than a metre. There were no macro-zooplankton in the plankton and the only grazer of $A$. fusiformis was the lesser flamingo, Phoeniconaias minor, which occurred irregularly in very high concentrations (in excess of $1 \times 10^{6}$ ). Detritivory in the benthos was effected by a single chironomid species, Paratendipes $\mathrm{sp}$., at a maximum density of $4 \times 10^{4} \mathrm{~m}^{-2}$. The mean daily emergence of adult chironomids was estimated to be 1 $\times 10^{3} \mathrm{~m}^{-2}$, the maximum 3 . There was no littoral plant community within the lake but 44 dicotyledonous and 31 monocotyledonous plant species in the drawn-down zone and adjacent to it. A diverse draw-down terrestrial invertebrate fauna, only superficially described here, processed the flamingo feathers and carcasses, with other detritus such as chironomid pupal exuviae and decaying A. fusiformis scum. About 50 bird species depended upon the chironomids, either as they emerged through the water column as flying adults or later on the shoreline as floating pupal exuvia and dead adults. The lake has high conservation value because of three bird species in particular - lesser flamingo, Cape teal and black-necked grebe. The former provides real economic value in a region otherwise impoverished, because of the spectacle of tens of thousands of flamingos set against the landscape of hot springs and fumaroles at the lake edge, which draws 15000 visitors per annum. $P$. minor has experienced three periods during the past ten years when major mortalities have occurred, the last of which killed 700 birds day $^{-1}$. This could have involved as many as 200000 birds (about $1 / 5$ th of the maximum population at this lake) if mortality was at a constant rate for the nine months it was observed. Causes of mortality have been suggested as avian tuberculosis, poisoning from cyanobacterial toxins or from heavy metal contamination at Lake Nakuru, but it is still not yet clear what contribution each makes to the problem.
\end{abstract}




\section{Introduction}

Biodiversity is a word with a short life history, even though Henri Dumont has been a practitioner of it for his long and productive professional life. Probably first used in 1984 at a conference in Washington DC, U.S.A. (Wilcox, 1984) and several times in quick succession thereafter (Wilson, 1987, 1988), the number of times it was used in the literature accelerated through the early 1990s (Harper \& Hawksworth, 1994). Its entry into everyday English is a result of its widespread use at the 1992 Rio de Janeiro Conference on Environment \& Development (popularly called the Earth Summit). This UN Conference helped to focus global attention on the rates of loss of biodiversity - extinction of species and populations - that are now considered so alarmingly high by many scientists as to threaten the life-support systems of our planet (Wilson, 2002). At best, deterioration of these lifesupport systems will be financially crippling (Constanza et al., 1997), at worst it will reduce the capacity of the planet to sustain humans (e.g. water resources; Vosmarty et al., 2000).

Henri's life has been devoted to improving our knowledge of aquatic biodiversity and limnology. On the one hand he has made considerable advances in taxonomy, particularly of crustacea, and on the other hand he has advanced our understanding of aquatic ecosystems and their processes through his development of Hydrobiologia. An aquatic ecosystem promoted extensively in this journal has been the saline lake, particularly through the inclusion of the edited conference proceedings of six scientific meetings devoted to it (e.g. Melack et al., 2001). Saline lakes present several interesting facets of aquatic biodiversity and Lake Bogoria, Kenya, illustrates these par excellence. There has been no previous publication specifically on this lake's limnology or biodiversity and it is appropriate therefore, that the first one appears in this volume.

Much of the knowledge of saline lakes in Africa has come from studies of their chemistry (e.g. Talling \& Talling, 1965; Wood \& Talling, 1988), biodiversity (e.g. Jones et al., 1994) and the magnitude of their primary production (e.g. Melack \& Kilham, 1974; Melack, 1981). It is well understood that saline lakes have a limited species complement in macroorganisms in contrast to considerable biodiversity in micro-organisms (Beadle, 1981; Grant et al., 1990; Duckworth et al., 1996) and that production of the few species that dominate each trophic level is high
(Vareschi, 1987). Attention has now focussed on their temporal dynamics (Verschuren et al., 1999), because of the fundamental scientific interest but increasingly because of the applied value in understanding human interference with their hydrological balance [e.g. Mono lake, California (Jellison et al., 2001) and Lake Nakuru, Kenya (Anon, 2003)]. In African saline lakes, this applied value has a unique facet because these lakes have economic value to the local human population through tourism based almost entirely on one species - the lesser flamingo (Phoeniconaias minor Geoffroy).

P. minor is the major primary consumer in East African saline lakes in particular, but also in South Africa and parts of West Africa (Simmons, 2000), filtering the planktonic cyanobacterium 'spirulina' (Ridley et al., 1955), Arthrospira fusiformis (Voronichin) Komárek (Hindák, 1985) together with shallow littoral diatoms in lakes and a wider range of cyanobacteria and diatoms in temporary wetlands (McCullough et al., 2003) These flocks of P. minor give the term 'biodiversity value' an unusual slant, because it is elsewhere generally synonymous with species diversity. Lake Nakuru, the first protected area in Africa for birds alone (and Kenya's first Ramsar site), was primarily purchased and conserved for this one species; is the second most visited National Park in Kenya and was considered "the most fabulous bird spectacle in the world" by Roger Tory Petersen (Williams, 1967). Lakes Bogoria and Elmenteita are the other two Kenyan saline lakes used extensively by $P$. minor (Owino et al., 2001). The former is a protected National Reserve and Ramsar site; the latter privately owned but managed sympathetically. P. minor occurs in flocks of over a million individuals at these lakes (see below) but is considered to be a 'nearthreatened' species (Hilton-Taylor, 2000), because the numbers are only about half of those formerly recorded [1.5 million Lake Nakuru (Vareschi, 1978), 2 million Lake Bogoria, (Brown, 1959)] and it only has one regular breeding site in East Africa and breeds there only intermittently - Lake Natron in Tanzania. Moreover, three large mortalities of $P$. minor have occurred in Kenya in the previous decade; both at lakes Bogoria and Nakuru in late 1993 and late 1995, at Lake Bogoria alone in late 1999. At least 40, 20 and $80 \times 10^{3}$ birds, respectively are estimated to have died in these three incidents (by subjective media reports at the time; no scientific numbers have been published). Two decades earlier, in late 1973 several hundred birds had died at Lake Nakuru, coincident with a 
sharp decline in the biomass of their food (Vareschi, 1978) and avian tuberculosis was identified in postmortems (Cooper et al., 1975; Sileo et al., 1979). The deaths during the 1990s, currently not convincingly explained, threaten $P$. minor's economic value through depleting tourist income, as well as its conservation status.

P. minor is a nomadic species, moving between the lakes on which it feeds at irregular intervals in unpredictable numbers. Leslie Brown, the first biologist to study flamingos objectively in the 1950s and who discovered their breeding sites (Brown \& Root, 1971) wrote "Personally, I hope that no one ever will fully rationalise flamingos, and that they will remain the supremely beautiful, elusive, opportunistic, unpredictable beings I like to think they are" (Brown, 1979). Their nomadic behaviour has probably evolved as a response to the unpredictable dynamics of their food supply in the short-term and the unpredictable status of the lakes in the long-term.

Most of the Rift Valley lakes have shown major hydrological changes on a time scale of centuries and longer, their limnology alternating between saline and fresh, from the paleolimnological evidence in sediment cores (e.g. Lake Abiyata, Ethiopia; Legesse et al., 2002; Chalié \& Gasse, 2002). Lakes Elmenteita and Nakuru were once joined, forming a single large freshwater lake (Nilsson, 1932) but are currently separate, shallow and saline. Nakuru has dried up 7 times in the past 70 years (Vareschi, 1978; Nasirwa, 2000) and Elmenteita also at least once per decade (I. Marshall, pers. comm.). Both lakes experienced an order of magnitude change in their alkalinities over 8 years in the 1960s, between 122 and 1440 meq $1^{-1}$ (Livingstone \& Melack, 1984). Bogoria was also once part of a larger freshwater lake, joined with the current Baringo (Nilsson, 1932) but by contrast with the other two, it is currently still moderately deep, with a maximum depth recorded as $12 \mathrm{~m}$ (Vareschi, 1978). It is thus likely to be both physically and chemically more stable than the other two in drought conditions.

Lakes Nakuru and Elmenteita were intensively studied during the 1970s for several consecutive years (Vareschi, 1982; Melack, 1988). These authors recorded one longer period of stable, high photosynthesis and biomass in the early seventies and one short period of unstable, low photosynthesis and biomass in 1974. It was hypothesised then, that the changes were triggered by the rate of increase in salinity as water level declined in drought conditions (Melack, 1988). This decrease in primary producer biomass also resul- ted in decreases in P. minor at these lakes (Vareschi, 1978; Tuite, 2000). Lake Bogoria was sampled less often during this period of study in the 1970s (see below) and so the extent to which Bogoria is more stable than the two other lakes remains unclear.

The objectives of this study were to establish whether the chemical and biological parameters of Lake Bogoria are more stable than those of the two shallow lakes and what the consequences of chemical changes might be for lake ecology and biodiversity, particularly flamingo behaviour and biology.

Some preliminary measurements (not hitherto published) were recorded in the open water in the 1970s; an investigation of the microbial flora of lake water was undertaken over one year in 19889 and then five visits were made between February 2000 and February 2003 in which both limnology and biodiversity were investigated. This paper describes the lake's limnology and its links to the $\mathrm{Na}$ tional Reserve's biodiversity, from these three periods. It forms a prelude to a longer multidisciplinary project, funded by the U.K. Darwin Initiative (http://www.darwin.gov.uk/projects.htm) which will make monthly visits from July 2003-June 2006.

\section{Study site}

The Eastern (Gregory) Rift Valley of Africa contains several dozen lakes ranging in size from Lake Turkana, $250 \mathrm{~km}$ long, in northern Kenya to many small $(<1 \mathrm{~km})$ volcanic crater lakes. All of them are endorheic in depressions on the valley floor or inside volcanic craters. Most of them, as a consequence, are saline to a greater or lesser degree (Talling \& Talling, 1965). Lake Bogoria lies in a trough, created by tilt faulting which is characteristic of this area of the Rift in northern Kenya (Fig. 1). It is $16 \mathrm{~km}$ long and $1-4 \mathrm{~km}$ wide, on a north-south axis with three basins between two 'necks' formed by raised ground.

The rainfall pattern of this area is complicated by the topography of the Rift here, which widens in a triangular shape northwards with Bogoria close to the southern apex. Precipitation is influenced by both the Rift's escarpments and by mountain ranges rising from the widened Rift floor. The lake itself lies in a relatively low altitude $(975 \mathrm{~m})$, low rainfall area (mean $708 \mathrm{~mm}$ 1976-2001) and experiences two rainy periods associated with the Inter Tropical Convergence Zone in April-May and October-November plus an additional July-August peak attributed to a westerly 


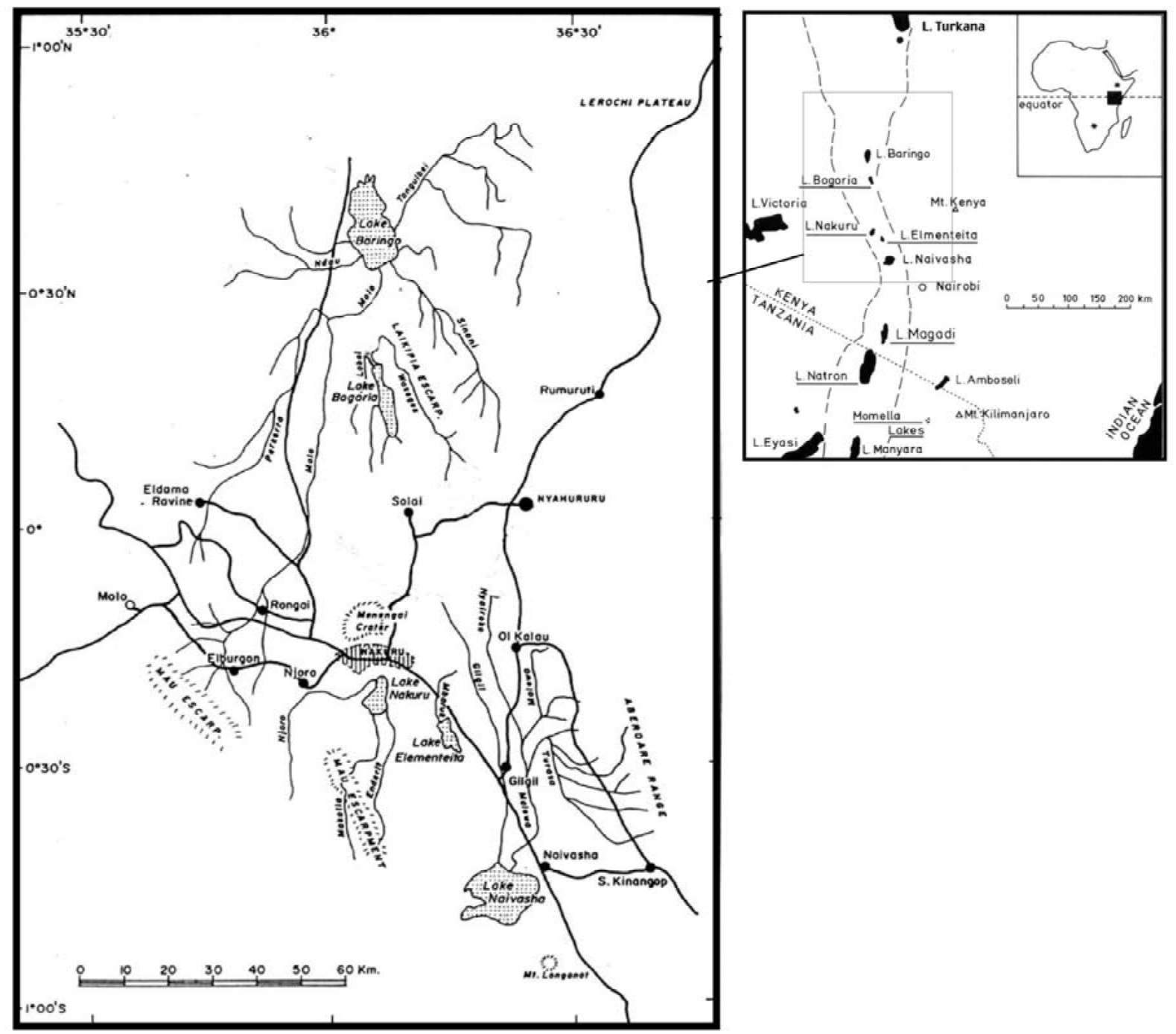

Figure 1. Saline lakes (names underlined) within the lake series in the floor of the Gregory Rift Valley of Kenya. Modified from Vareschi (1978).

air stream (Davies et al., 1985; LaVigne \& Ashley, 2001). The hydrology of the lake is complicated by the inflow from numerous hot springs along its western and south-eastern shoreline in addition to its 5 river inflows. Three of these are permanent; two small freshwater streams, fed by springs, enter in the south while one river, the Ndolaita-Loboi, which formerly flowed northwards, has been diverted for irrigation and flows in the northern end of the lake. Two seasonal rivers, with substantial deltas, enter the north and west (Fig. 2).

The chemistry of the lake was initially studied by Jenkin (1936), Talling \& Talling (1965), Vares- chi (1978) and Melack (1981). The latter two papers recorded that the lake had a temperature range of $24-31^{\circ} \mathrm{C}$, conductivity of $72-77 \mathrm{mS} \mathrm{cm}{ }^{-1}$, alkalinity $1500 \mathrm{meq} 1^{-1}$, and $\mathrm{pH}$ of $10.2-10.3$ in 1974 . Its general alkaline state is a result of strong equatorial evaporative concentration, which leaves a sodiumand carbonate- dominated solution (Livingstone \& Melack, 1984; Grant et al, 1990).

\section{Methods}

The lake outline was taken from the 1:50000 maps of the Survey of Kenya, 1973, which were based on aerial 
photographs flown in January-February 1969. Bathymetry was measured from an inflatable dinghy during the period 16-26th August 2002 using a Lowrance $\mathrm{X}-15 \mathrm{~A}$ chart recording echo-sounder with a $20^{\circ}$ transducer beam. Positions of key depth readings were located with a Garmin 12 hand-held GPS receiver, enabling contours and maximum depths to be mapped.

Water samples from 1972-78 and 2000-3 were collected in replicate from a dinghy in open water stations over the deepest point in each of the three basins; in 1988-9 from the western shore at two locations in $30 \mathrm{~cm}$ of water depth on 12 consecutive monthly occasions. Water samples were collected at predetermined depth intervals from Rutner bottle (1972-8) and either from a rubber tube and pump (from the upper half metre) (1972-78) or a plastic Van Dorntype messenger-closed 1.251 sampling bottle (from 1 $\mathrm{m}$ and below) (2000-3). Secchi disc transparency was measured using the extinction of a $20-\mathrm{cm}$ diameter black and white quartered disc. Conductivity and temperature were measured using a WTW conductivity meter with Withney electronic thermometer (1972-8), Markson portable conductivity meter with automatic temperature correction (1988-9), YSI (Yellow Springs Electrode company) model 50 Conductivity meter (2000-2) and YSI 6600 Multiparameter Sonde (2003). $\mathrm{pH}$ was measured on WTH, Pye-Unicam Gingold, Hach and YSI instruments. Oxygen was measured by Winkler titration (1972-8) and YSI model 58 meter (2000-3). Alkalinity was titrated with $0.1 \mathrm{~N} \mathrm{HCl}$ using phenolphphalein and Bromocresol Green-Methyl Red indicators.

Viable counts of bacteria on the lake water collected in 1988-9 were made by Colony Forming Units (CFU) cultured on Horokishi medium modified by addition of $4 \% \mathrm{NaCl}$, for $48 \mathrm{~h}$ at $37^{\circ} \mathrm{C}$. Total counts were made using epifluorescence microscopy on a water sample with acridine orange stain, filtered through black Millipore filter $(0.22 \mu$ pore size). Immersion oil was placed on the filter paper and bacteria counted at $1000 \times$ magnification on a Leitz microscope with blue epifluorescence light.

A. fusiformis was counted microscopically, a minimum of 4 times on each water sample, by mounting $1 \mathrm{ml}$ of shaken sample in a plastic Sedgwick Rafter cell and then counting 20 squares at random under 40 or $100 \times$ magnification on a compound microscope. Numbers of colonies of A. fusiformis were counted and then number of coils calculated from a single determination of the mean number of coils per colony for each visit. Other phytoplankter species were searched for using a microscope at 100 and $400 \times$ magnification from a composite sample.

A fixed volume of each water sample was filtered through Whatman GFC filter paper to retain the phytoplankton. The papers were placed in the dark until all samples had been filtered for chlorophyll ' $a$ ' determination. When filtering was complete, the papers were each cut into strips and then ground in a pestle and mortar in a small quantity of $90 \%$ alkaline acetone and a pinch of sand for 5 minutes. The contents were carefully washed using more acetone into a $15 \mathrm{ml}$ centrifuge tube after no green flecks could be seen, the tube made up to the mark and then centrifuged for 5 min at maximum speed on a hand-operated centrifuge. The liquid was carefully decanted into matched glass tubes and read against acetone blank in a Hach DR 2000 portable spectrophotometer at 750 and $665 \mathrm{~nm}$. Phytoplankton chlorophyll ' $a$ ' pigment concentration was then determined using the approximate equation of Talling \& Driver (1963).

Primary production was measured in water collected from 15 to $25 \mathrm{~cm}$, enclosed in Winkler (1972-8) or $250 \mathrm{ml}$ 'Pyrex' glass reagent bottles (2003) which were suspended at the same point in the lake in pairs horizontally and pairs in light-proof containers vertically, at fixed depths for a measured time. Oxygen concentrations were measured at beginning and end by Winkler determination (1972-8) or YSI Model 58 Oxygen meter with pre-calibrated BOD probe immersed in the bottles and mechanically-agitated (2003).

Benthic samples were taken from measured depth with an Ekman grab of $15 \times 15 \mathrm{~cm}$ and the mud filtered through a 25 micron mesh sieve over the side of the boat. Invertebrates were sorted live and counted in the laboratory, then blotted with damp tissue paper and wet-weighed, before preservation in 70\% alcohol.

Flowering plant species growing within the drawdown zone and within $100 \mathrm{~m}$ of the current lake edge were identified from Agnew \& Agnew (1994), grasses from Weiss (1989), and sedges and rushes from Haines \& Lye (1983). Coleoptera inhabiting this zone and the riparian Acacia scrub were sampled by beating and sweeping using a standard entomologist's sweep net and by hand searching under the stones, dead wood and litter. A Heath portable moth trap in conjunction with a white suspended sheet was used for flying individuals. A series of pitfall traps was also used to sample the ground active coleoptera on vertical transects from the water's edge into the draw-down zone. 


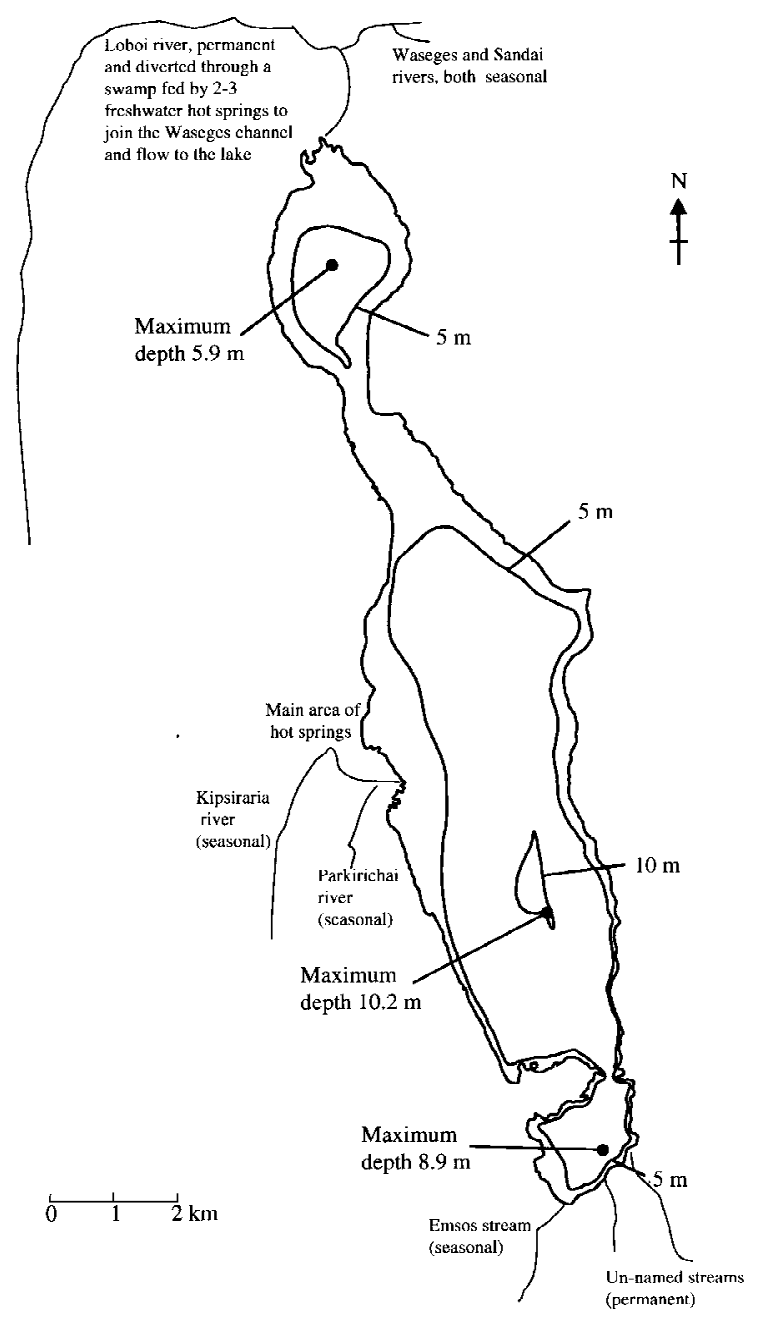

Figure 2. Details of Lake Bogoria showing inflows and bathymetry at August 2002 with $5 \mathrm{~m}$ depth contours and positions at which maximum depth was recorded in the three basins.

Bird species were identified using $10 \times 42$ binoculars and the Field Guide of Stephen \& Fanshawe (2002) at all times during the visits 2000-3. Lesser flamingos on the lake were counted on each visit. Two-5 observers drove along the Reserve road from the south-west corner to the north-west. The vehicle stopped at every vantage point to divide the shore up into recognisable small sections, with one or more 'flocks' of birds. Each observer then recorded the numbers by counting 100 and estimating the number of 100-bird subgroups in the flock, using binoculars $(10 \times 42)$ or telescope $(20-60 \times$ zoom $)$ to view the eastern shore. The observers worked independently; if their numbers were $<5 \%$ of each other an average of the group was taken; if it was greater the count was repeated by all. At the end of the day the numbers in the sections were summed.

In February and December 2000, and August 2001, the mortality of $P$. minor was calculated from daily censuses at dawn of 5, 1-km lengths along the north and western shoreline in each basin over 12 consecutive days. Dead birds were removed from the shoreline before the start of the exercise and each day as they were counted. On one day, in the middle of the counting period, in 2000 , the eastern shores were walked in their entirety in order to quantify the carcasses that were there. On other dates in 2002 and 2003 mortality was estimated.

\section{Results}

The majority of the lake is deeper than $5 \mathrm{~m}$ (Fig. 2) with shallower areas associated with deposition from the inflowing rivers in the north and west and along the neck of the lake between the central and northern basins. The deepest point was $10.2 \mathrm{~m}$ in the central basin. Lake surface elevation is now regularly recorded at the southern shore of the lake (W. Kimosop, pers. comm.) and this shows that lake level decline has been about $2 \mathrm{~m}$, continuous for the last 3 years, which accounts for the deeper maximum published for the 1970s by Vareschi (1978).

The main chemical parameters showed some variation between 1972 and 2003 (Table 1). The largest change was in conductivity, which was half the value in 1978 and in 1988/9 that it achieved in 1974 or 2000 2003. There are no figures of lake level available for this period, but the rainfall collected at the Reserve indicate that the two periods of low conductivity corresponded to high rainfall associated with 'El Niño' events (77-79 \& 88-90). (The heavy rain commenced in April 1977; the conductivity was recorded in the first 2 months of that year). The limited range of parameters measured over this period nevertheless indicate that the lake water is well buffered against changes, with $\mathrm{pH}$ only changing between 0.7 units (bearing in mind each visit used different instruments) and alkalinity changing little between heavy rainfall periods (88-89) and drought periods (1974 and 2000-3).

Replicates taken either from the north and south basins in 1988-9 or from a boat in all three basins in 2002 and 2003, resulted in low variance, indicating spatial uniformity throughout the lake. In August 1978 however, the middle of the 'El Niño' event, clear 
Table 1. Chemical parameters recorded at Bogoria from 1972 to 2003

\begin{tabular}{|c|c|c|c|}
\hline & $\mathrm{pH}$ & $\begin{array}{l}\text { Conductivity } \\
\mathrm{mS} \mathrm{cm}^{-1}\end{array}$ & $\begin{array}{l}\text { Alkalinity } \\
\text { meq } 1^{-1}\end{array}$ \\
\hline $1972-3(n=4)$ & 10.0 & 52.3 & \\
\hline $1974(n=2)^{*}$ & 10.25 & 74.5 & 1500 \\
\hline $1975-7(n=3)$ & 10.3 & 59.0 & \\
\hline $1978(n=2)$ & 10.1 & 44.0 & \\
\hline $1988 / 9(n=24)$ & $10.7^{+} /{ }_{-} 0.2$ & $36.8^{+} /{ }_{-1} 1.7$ & $1160^{+} /{ }_{-} 14.2$ \\
\hline $2000-3(n=12)$ & $10.3^{+/}-0.25$ & $74.2^{+} /{ }_{-} 2.6$ & $1190(n=1)$ \\
\hline
\end{tabular}

*From Vareshi (1978) and Melack (1981); one measurement published in each.

chemical stratification was recorded in the south basin only, with the upper $5 \mathrm{~m}$ showing $60 \%$ of the conductivity of the deeper layers (Fig. 3a), which was not mirrored by $\mathrm{pH}$ differences (between 10.1 and 10.2 at all depths).

Very clear vertical stratification of oxygen was recorded on every boat sampling occasion from 1972 to 2003. In the south basin (sheltered) the oxycline always occurred between 1 and $2 \mathrm{~m}$ (Fig. 3b), but in the north and central basin (more exposed to prevailing winds) it was replaced by a more gradual decline from super-saturation at the surface to anoxia below $5 \mathrm{~m}$. The surface waters were always supersaturated with oxygen, up to to $300 \%$ during the daylight hours, with a daily maximum in the afternoon between 1500 and 1700 (Fig. 3c). The temperature, by contrast, varied relatively slightly. The water below $4 \mathrm{~m}$ was between 23 and $25^{\circ} \mathrm{C}$ on every occasion the lake was studied between 1972 and 2003. Surface water was at the same temperature morning and evening, but rose as high as $32{ }^{\circ} \mathrm{C}$ in the upper metre (Fig 3d).

Biological characteristics indicated up to an order of magnitude variation between sampling occasions (Table 2), with biomass of chlorophyll ' $a$ ' from 38 to $363 \mathrm{mg} \mathrm{m}^{-3}$. The density of $A$. fusiformis and the chlorophyll biomass varied approximately fivefold between 2000 and $2003\left(2.7-21 \times 10^{3}\right.$ coils $\mathrm{ml}^{-1}$ and $38-165 \mathrm{mg} \mathrm{m}^{-3}$ chlorophyll ' $a$ ') with a progressive rise through the four years. The low frequency of visits may give a deceptive air of stability, because a lake-wide $A$. fusiformis crash occurred in October 2001 (Nasirwa, pers. obs.), with aroma from the decay detectable several kilometres from the lakeshore (Kimosop, pers. comm.), although it is not known what the consequences were for succession or primary production, and no adverse effects of $P$. minor occurred. In all years studied A. fusiformis was the overwhelmingly dominant phytoplankton species. It represented over $70 \%$ of the community sampled throughout 1988-9 when the sample was collected from the shallow littoral but $100 \%$ of the true plankton community in 1972-8 and 2000-3 with no other species entering the counts. Diatoms were occasionally seen in the plankton, but were most likely vagrants from the shallow mud and hot springs inflow streams, where 34 species have recently been recorded (EscutéGasulla et al., 2002) (see also Gasse, 1996). Other cyanobacteria were also common in the hot inflow streams.

Spatial differences in A. fusiformis density and biomass occurred between basins on any one day, of up to 2-3 times, but this was not great enough to show differences in transparency. Observations from the air and from lake-side vantage points, indicated that wind-generated slicks concentrated lines of $A$. fusiformis, which attracted feeding $P$. minor; this short-term spatial pattern will be the subject of another paper (Vareschi, Mills, pers. obs.). Vertical differences within slicks could however be extreme; in May 1972 biomass of $A$. fusiformis in the top $5 \mathrm{~cm}$ was 20 times greater than that in the upper $25 \mathrm{~cm}$.

The primary production of phytoplankton was confined to the upper metre of water surface, in all years when measured - 1972, 1974 and 2003. Net production ranged between 0.8 and $3.3 \mathrm{gm} 0^{2} \mathrm{~h}^{-1}$, or $0.2-1$ $\mathrm{gm} \mathrm{Ch}^{-1}$.

Six strains of mainly gram-negative alkaliphilic bacteria, such as Vibrio sp., were commonly recorded in the water of Lake Bogoria during the 12 months when its microbial community was studied, 1988-9. Three of them, which occurred every month, accounted for over half the density. Overall, the mean density expressed as CFU was $3.85 \times 10^{5} \mathrm{ml}^{-1}$, two orders of magnitude lower than the total epifluorescence count of planktonic bacteria. The taxonomy of these alkaliphiles is a poorly-understood area still being investigated (W.D.Grant, pers comm.).

There were no zooplankton above the size of protozoa in the water column at any time and only a single chironomid species of zoobenthos grazer/detritivore. This species, tentatively identified as Paratendipes sp., occurred in high densities throughout the lake above the anoxic depths (Fig. 4), with no difference between lake basins or between sampling date, 2000-2003. Maximum larval densities at $1-2 \mathrm{~m}$ depth were $3.9 \times$ $10^{4} \mathrm{~m}^{-2}$ (wet weight $65.3 \mathrm{~g}$ ), with a mean for the lake 

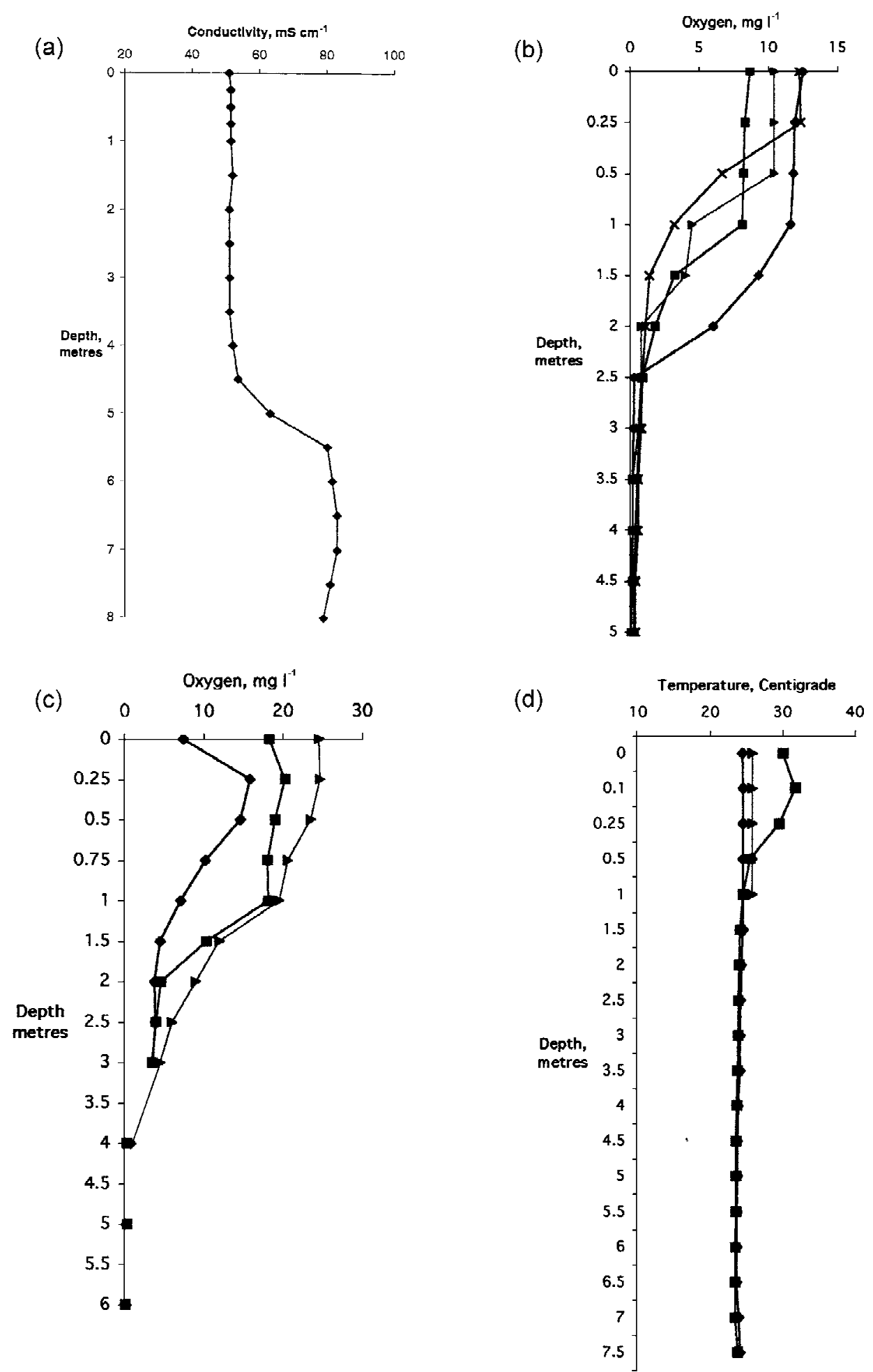

Figure 3. Vertical stratification of chemical parameters at Lake Bogoria, 1972-2003. (a) conductivity stratification in August 1978. (b) Oxygen stratification in February 2000 (diamonds), February 2001 (squares), October 2002 (triangles) and February 2003 (crosses). (c) Diurnal pattern of oxygen supersaturation in August 1978 between $1100 \mathrm{hrs}$ (diamonds), $1500 \mathrm{hrs}$ (square) and $1700 \mathrm{hrs}$ (triangles). (d) Temperature stratification in February 1972 between 0800 hrs (diamonds), 1300 hrs (squares) and 1700 hrs (triangles). 
Table 2. Biological parameters recorded at Bogoria from 1972 to 2003

\begin{tabular}{lrrrrrrrr}
\hline Month/Year & 1972 & $1974^{*}$ & 1978 & $1988-9$ & $02 / 2000$ & $2001^{1}$ & $10 / 2002$ & $03 / 2003$ \\
\hline Secchi disc cm, mean & - & 36.5 & - & - & 53 & 23 & 19 & 18 \\
standard deviation or range & & $28-45$ & & & 5.7 & 3.7 & 2.3 & 1.1 \\
$n$ & & 2 & & & 9 & 18 & 22 & 18 \\
Chlorophyll mg m & -3 \\
standard mean deviation or range & 163 & 350 & 276 & 363.3 & 37.9 & 56.8 & 142.1 & 165.2 \\
$n$ & 74 & $150-800$ & 60 & 487.7 & 4.8 & 24.4 & 24.3 & 79.4 \\
A. fusiformis coils ml & 12 & 2 & 4 & 24 & 20 & 12 & 9 & 10 \\
standard deviation & 2773 & - & & - & 3375 & 11639 & 14520 & 20826 \\
$n$ & 750 & & & & 1652 & 2152 & 1325 & 1151 \\
& 15 & & & & 23 & 12 & 11 & 15 \\
\hline
\end{tabular}

*From Melack (1981).

${ }^{1}$ A. fusiformis counted March-June, but chlorophyll measured in March \& August.

under $5 \mathrm{~m}$ of $1.4 \times 10^{4} \mathrm{~m}^{-2}$, (wet weight $20.4 \mathrm{~g}$ ). Adult emergence appeared to be continuous; with an estimated life cycle of 2 weeks (given the adult size and lake temperature), so the maximum daily production could be 3000 adults $\mathrm{m}^{-2}$, mean $1000 \mathrm{~m}^{-2}$. A conservative wet weight biomass is in the order of 3 tonnes, with a daily emergence of $210 \mathrm{~kg}$, for the whole lake. This sustains several thousand individual avian predators; the most numerous are swifts and swallows and the most important for biodiversity conservation are the Cape teal and black-necked grebe (see below).

The density of $P$. minor, major grazer of the phytoplankton in the lake Bogoria ecosystem, varied rapidly, doubling or halving during the two and a half weeks of a sampling campaign, so the interpretation of numbers over a short time scale without substantial accompanying environmental data would be misleading. Its minimum numbers were 30000 in February 2003, its maximum 510000 in August 2001.

The most recent and the largest mortality of this species is believed to have commenced in July 1999 (Gough, 2000) and petered out in March 2000 (W. Kimosop, pers. comm.). The average daily mortality on the western side of the lake in late February 2000, was $28.8^{+} /-5$ individuals $\mathrm{km}^{-1}$, with no evidence of either temporal (over 12 days) or spatial (between basin) differences. On the single count of south and eastern shores, only 25 flamingo carcasses, of all stages of decay, were recorded, which indicated that prevailing winds brought almost all carcasses to the western shore. Extrapolating the western shore counts to the length of shoreline exposed (west and north), gives a daily mortality for the lake of approximately 700 birds. This leads to a speculative mortality of $2 \times 10^{5}$ deceased birds for the nine months of the event, equivalent to about $20 \%$ of the late-1990s observed population (Owino et al., 2001). Comparison of this with mortality estimates subsequently made, in December 2000, August 2001, October 2002 and February 2003, suggest that smaller peaks of mortality occur on top of a base mortality (approximately $0.01 \%$ would be an average daily mortality of a bird with lifespan estimated at between 35 and 50 years). In December 2000-January 2001, when the number of $P$. minor went from 40000 to 297000 in 3 weeks, average mortality was measured as $9+/-4$ birds day ${ }^{-1}$. In August 2001, however, when between 510000 and 325000 birds were counted at the lake, 113.5 day $^{-1}$ died. In October 2002 and February 2003, fewer birds were present $-92-94 \times 10^{3}$ and 40-20 $\times 10^{3}$, respectively. Whole-lake mortality was estimated (not counted) as no higher than 10 per day, but at this low number it was difficult to distinguish between birds healthy but predated (by marabou stork, fish eagle or steppe eagle) and birds which had been close to death and were scavenged. Visual examination of the weak birds - between 20 and 50 - in a sub-population of circa 5000 on each of 12 days in February 2003, showed that less than 1 in 20 of weak birds was 'sick' (characteristic staggering and headdrooping): the remainder had visible damage to limbs (and occasionally wings) but held necks up, so were 'injured'.

In 2002 and 2003, over 50\% of the population at the lake consisted of birds under 2 years old (white-grey plumage), which indicate that breeding had replaced the 2000 mortality. Breeding was still in evidence by March 2003, with an estimated 20000 


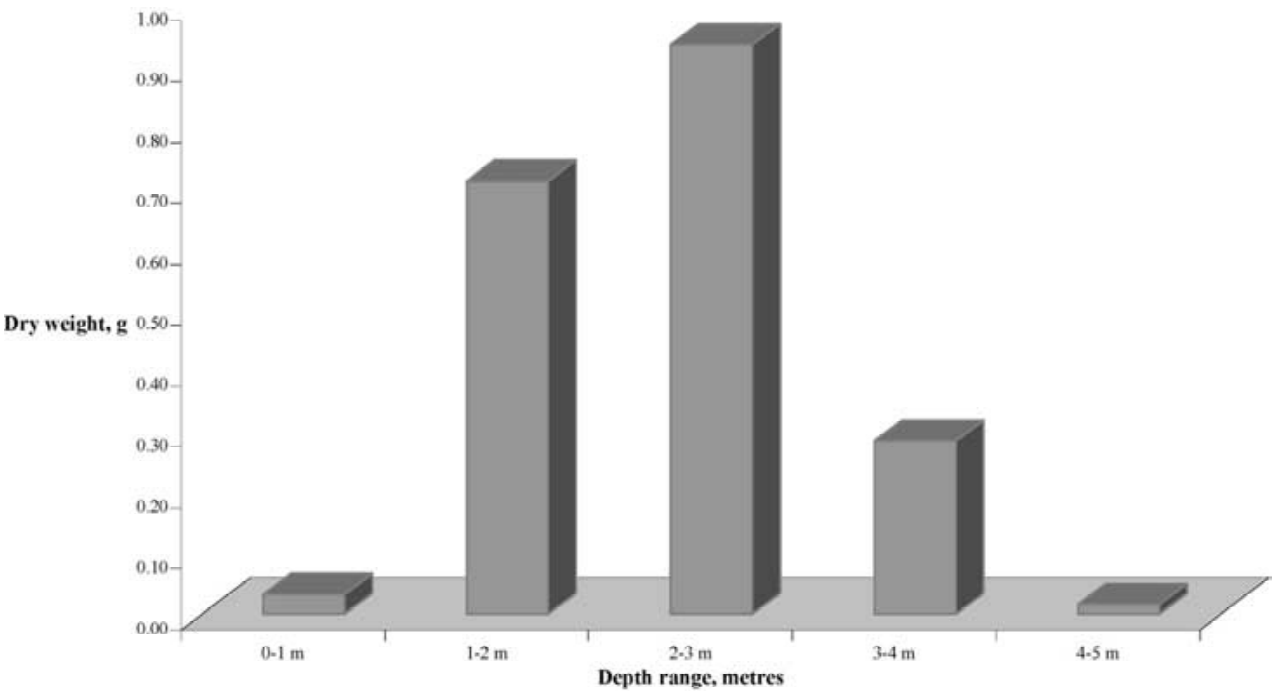

Figure 4. Mean distribution of wet weight of larvae of the midge Paratendipes sp. from 36 Ekman grab samples in February 2002. The standard deviations are not shown because the variances were very high $(\mathrm{SD}=/>$ mean) due to extensive density variation under $2 \mathrm{~m}$ depth.

chicks visible on Lake Natron (DMH, MMH, EV \& A. Simpson, pers obs.).

No aquatic higher plants occurred in the lake. However, a diversity of plants have colonised the draw-down zone. Twenty-three families and 27 species of herbs and low-growing shrubs were recorded close to the shore (Table 3). Plant densities, although not necessarily species richness, were low in all areas other than around freshwater inflows. Adaptions to water stress, salt stress and removal by herbivores appeared to be more important in shaping the plant community than competitive interactions between individuals or closely related species. The high plant taxonomic diversity at family level is consistent with the wide range of habitats that are created by different substrate, salinity and water table depths and with a considerable breadth of plant adaptations to environmental stress. Selection appears restricted to the level of genus with typically only one or two species in each genus. The shoreline was rich in grass species, with 27 species. Of these, only Sporobolus spicatus and Cyperus laevigatus are true halophytes. The ratio of monocots to dicots in the ground flora was $1: 1.3$, which is much closer to the ratio expected in aquatic plant communities than the ratio of $1: 4$ more typical for terrestrial plants. Only three herbaceous species; the two lilies and the Commelina sp., are monocotyledons. The Liliiflorae are likely to have been under-represented, as bulbs and tuberous roots sometimes uncovered in dry and stony areas, had no evidence of aerial growth.

The water's edge consisted of a marginal 'drift' of flamingo feathers, remains of flamingo carcasses, bird droppings and vegetation debris, overlying rockstrewn gritty mud. This attracted high numbers of coleoptera, particularly tenebrionids, such as Gonocephalum sp., Sepidium spp. Vietomorpha spp., and Rhytinota praelonga Koch to nocturnally scavenge and shelter by day under stones. During the day the lake margin was dominated by Zophosis spp. and the predatory cicindelid (tiger beetle), Lophyra boreodilatata (Horn), commonly 'hawking' and running over the mud and bare sands. The lake edge scrub supported many cerambycids (longhorn beetles), including the large prionids, Tithoes confinis Castelnau and the ubiquitous Macrotoma palmata (Fabricius), which are primary agents in breaking down dead wood. Tiger beetles caught in light traps were Prothyma methneri methneri Horn, Cylindera rectangularis (Klug), Myriochile vicina pseudovicina (Mandl). In wetter periods Scarabaeidae dominated light trap catches, particularly rutelids and melolonthids. Elaterids (click beetles) were common, including the $6-7 \mathrm{~cm}$ long Tetralobus spp.

The vegetated riparian zones, which run down to the lake, contain quite mature Acacia tortilis and A. seyal, often overgrown with Salvadora persica and Capparis spp., in groves close to freshwater inflows and springs and A. mellifera in the drier areas. The 
Table 3. Taxonomic list for ground-layer and low-growing shrub vegetation within $100 \mathrm{~m}$ of the lakeshore in Lake Bogoria National Reserve, August 2001 \& 2002. Nomenclature follows Agnew \& Agnew (1994). Grasses not found in this study but recorded by Onkware (1996) are marked with an asterisk

Acanthaceae

Hypoestes aristata (Vahl) Roem. \& Schultes

Crossandra mucronata Lindau

Barleria spinisepala E.A. Bruce

Aizoaceae

Mollugo nudicaulis Lam.

Amaranthaceae

Achyranthes aspera L.

Sericocomopsis hildebrandtii Schinz

Asclepiadaceae

Calotropis procera (Ait.) Ait.f.

Boranginaceae

Heliotropium steudneri var. steudneri

Capparaceae

Maerua decumbens (Brongn.) De Wolf

Capparis tomentosa Lam.

Commelinaceae

Commelina petersii Hassk.

Compositae (Asteraceae)

Kleinia squarrosa Cuf.

Euphorbiaceae

Acalypha fruticosa Forsk.

A. psilostachya Hochst.

A. racemosa Baill.

Ricinus communis L.

Labiatae

Leonotis nepetifolia (L.) Ait.f. var. africana

Leucas sp.

Liliiflorae (Amaryllidaceae)

Scilla hyacinthia (Roth.) Alston

Liliiflorae (Asparagaceae)

Asparagus racemosus Willd.

Malvaceae

Abutilon fruticosum Guill. \& Perr.

A. mauritianum (Jacq.) Medic.

Hibiscus meyeri Harv.

$H$. vitifolius $\mathrm{L}$.

Pavonia patens (Andr.) Chiov.

Orobanchaceae

Orobanche minor Smith

Papilionaceae

Indigofera volkensii Taub.

Vigna schimperi Bak.

Pedaliaceae

Sesamum latifolium Gillett

Plumbaginaceae

Plumbago zeylanica L.
Table 3. Continued

Portulacaceae

Portulaca foliosa Ker-Gawl.

P. kermesina N.E.Br.

P. quadrifida $\mathrm{L}$.

Scrophulariaceae

Cycnium tubulosum (L.f) Engl.

Striga gesnerioides (willd.) Vatke

Solanaceae

Lycium europaeum L.

Solanum incanum L.

S. nigrum L.

S. renschii Vatke

Vitaceae

Cissus quadrangularis L.

C. rotundifolia (Forsk.) Vahl

Verbinaceae

Lantana camara (exotic)

Zygophyllaceae

Tribulus terrestris L.

Tribulus cistoides L.

Poaceae (grasses)

Andropogon sp.*

Aristida dimuta

A. keniensis*

A. somalensis

A. stenostachya

Bouteloua sp.

Brachiaria sp.*

Chenchrus ciliaris*

Chloris gayana

C. virgata

Cynodon dactylon

Cynodon nlemfuensis*

Dactyloctenium australe

D. bogdanii*

Elusine sp.

Enteropogon rupestris*

Eragrostis sp.

Heteropogon contortus

Paspalum sp.

Pennisetum sp.

Rhynchelytrum repens*

Sporobolus consimilis

S. keutrophyllus*

S. spicatus

Tragus berteronianus*

Typha domingensis

Urochloa raceme

Cyperaceae (sedges)

Cyperus cyperoides L. Kuntze

C. laevigatus $\mathrm{L}$.

C. rubicundus Vahl

Schoenoplectus corymbosus (Roth. ex Roem.

\& Schult.) J. Raynal var. brachyceras (A. Rich.) K. Lye Rottb 
acacias had a distinct coleopteran fauna in which the Buprestidae, Chrysomelidae and Curculionidae predominated. Some species infested the trees in population outbreaks, such as occurred in February 2000, when the eumolpine chrysomelid Malegia affinis Jacoby was the most abundant insect on the lake shore acacias.

The bird fauna consisted of 223 species recorded on the reserve between 2000 and 2003 and although most are not associated directly with the aquatic ecosystem, just over 50 species are directly dependent upon the lake and its associated mudflats, springs, streams, seepages and wetlands (Table 4). Up to another 50 terrestrial insectivorous species feed, in part, on the adult Paratendipes sp. when they settle on lakeshore scrub. Two aquatic species, are wholly also dependent upon the Paratendipes sp. and are more abundant at this lake than any other in Kenya; Cape teal Anas capensis and black-necked grebe Podiceps nigricollis. Both feed on the emerging pupae (grebe dive for them as they rise) and adults (teal dabble on the surface film collecting adults and shed pupal exuviae). The numbers of these species fluctuated considerably, but in August 2001, 2084 P. nigricollis and 663 A. capensis were counted. The families Apodidae (swifts) and Hirundinidae (swallows and martins), which have five and seven species respectively, fed extensively on emerging adults over the water. Conservative estimates, made in February 2000 and in February 2003, suggested the numbers of these two families over the lake at least matched those of $P$. minor on it. The lake is an important feeding station for four Palaearctic migrants, in both directions, being at the southern edge of Kenya's extensive northern arid district, particularly Hirundo rustica, Riparia riparia and Apus apus.

\section{Discussion}

The lake's chemical data suggest a more stable environment than has been recorded for the other saline, more shallow, lakes in Kenya, with no evidence for the major changes recorded in Elmenteita (Melack, 1988) and Nakuru (Vareschi, 1982) caused by drying-out. A $50 \%$ change in conductivity accompanied by little $\mathrm{pH}$ or alkalinity variations suggests that the measured fluctuations of an order of magnitude in A. fusiformis is more due to biological regulation rather than environmental effects, and it is close to its theoretical maximum, as has been recorded for deep crater lakes
Table 4. Taxonomic list of birds recorded at Lake Bogoria National Reserve, 2000-3, Family, scientific and English names

Struthionidae: Ostriches Common Ostrich Struthio camelus

Podicipedidae: Grebes

Little Grebe Tachybaptus ruficollis Black-necked Grebe Podiceps nigricollis

Pelicanidae: Pelicans Great White Pelican Pelecanus onocrotalus

Phalacrocoracidae: Cormorants Long-tailed Cormorant Phalacrocorax africanus

Ardeidae: Herons and Egrets Cattle Egret Bubulcus ibis

Yellow-billed Egret Mesophoyx intermedia Little Egret Egretta garzetta Great Egret Casmerodius albus Striated (Green-backed) Heron Butorides striatus Grey Heron Ardea cinerea Black-headed Heron Ardea melanocephala Scopidae: Hamerkop Hamerkop Scopus umbretta

Ciconiidae: Storks

Yellow-billed Stork Mycteria ibis Wooly-necked Stork Ciconia episcopus Marabou Stork Leptoptilos crumeniferus White stork Ciconia ciconia

Threskiornithidae: Ibises and Spoonbills Sacred Ibis Threskiornis aethiopicus Hadada Ibis Bostrychia hagedash Glossy Ibis Plegadis falcinellus African Spoonbill Platalea alba

Phoenicopteridae: Flamingos Greater Flamingo Phoenicopterus ruber Lesser Flamingo Phoeniconaias minor Anatidae: Ducks \& Geese

Egyptian Goose Alopochen aegyptiacus Spur-winged Goose Plectropterus gambensis Knob-billed Duck Sarkidiornis melanotos White-faced Whistling Duck Dendrocygna viduata Cape Teal Anas capensis

Accipitridae: Kites, Vultures, Eagles and Hawks Yellow-billed Kite Milvus parasiticus White backed vulture Gyps africanus African Fish Eagle Haliaeetus vocifer African Marsh Harrier Circus ranivorus Montagu's Harrier Circus pygargus Eurasian Marsh Harrier Circus aeruginosus Pallid Harrier Circus macrourus Dark Chanting Goshawk Melierax metabates Gabar Goshawk Micronisus gabar

Continued on p. 271 
Table 4. Continued

Black-chested snake eagle Circaetus pectoralis African Harrier-Hawk Polyboroides typus Augur Buzzard Buteo augur Common Buzzard Buteo buteo Tawny Eagle Aquila rapax Steppe Eagle Aquila nipalensis orientalis Verreaux's Eagle Aquila verreauxii Martial Eagle Polemaetus bellicosus Falconidae: Falcons

Pygmy Falcon Polihierax semitorquatus Peregrine Falcon Falco peregrinus Lanner falcon Falco biarmicus Eurasian Hobby Falco subbuteo Numididae: Guineafowls Helmeted Guineafowl Numida meleagris Phasianidae: Quails and Francolins Jackson's Francolin Francolinus jacksoni Crested Francolin Francolinus sephaena Common Quail Coturnix coturnix

Rallidae: Crakes and Rails Black Crake Amaurornis flavirostris Gruidae: Cranes

Grey-crowned Crane Balearica regulorum

Recurvirostridae: Avocets and Stilts Black-winged Stilt Himantopus himantopus Pied Avocet Recurvirostra avosetta

Charadridae: Plovers

Grey plover Pluvialis squatarola Spur-winged Lapwing Vanellus spinosus Crowned Lapwing Vanellus coronatus Black-headed Lapwing Vanellus tectus Kittlitz's Plover Charadrius pecuarius Three-banded Plover Charadrius tricollaris Common Ringed Plover Charadrius hiaticula Chestnut banded plover Charadrius pallidus Scolapacidae: Sandpipers and Snipes

Lesser Sandpiper Charadrius mongolus Common Sandpiper Actitis hypoleucos Ruff Philomachus pugnax Wood Sandpiper Tringa glareola Green Sandpiper Tringa ochropus Common Greenshank Tringa nebularia Marsh Sandpiper Tringa stagnatilis Spotted Redshank Tringa erythropus Little Stint Calidris minuta Curlew Sandpiper Calidris ferruginea Common Snipe Gallinago gallinago Broad-billed sandpiper Limicola falcinellus Pteroclidae: Sandgrouse

Lichtenstein's Sandgrouse Pterocles lichtensteinii
Table 4. Continued

Columbidae: Pigeons and Doves

African Green-Pigeon Treron calva

Speckled Pigeon Columba guinea

Emerald-spotted Wood-Dove Turtur chalcospilos

Namaqua Dove Oena capensis

Ring-necked Dove Streptopelia capicola

Red-eyed Dove Streptopelia semitorquata

African Mourning Dove Streptopelia decipiens

Laughing Dove Streptopelia senegalensis

Musophagidae: Turacos

White-bellied Go-away-bird Corythaixoides leucogaster

Cuculidae: Cuckoos and Coucals

Klaas's cuckoo Chrysococcx klaas

White-browed Coucal Centropus superciliosus

Strigidae: Owls

African Scops-Owl Otus senegalensis

Verreaux's Eagle-Owl Bubo lacteus

Pearl-spotted Owlet Glaucidium perlatum

Caprimulgidae: Nightjars

Slender-tailed nightjar Caprimulgus clarus

Apodidae: Swifts

Little Swift Apus affinis

White-rumped Swift Apus caffer

Mottled Swift Apus aequatorialis

Nyanza Swift Apus niansae

Eurasian Swift Apus apus

Coliidae: Mousebirds

Speckled Mousebird Colius striatus

Blue-naped Mousebird Urocolius macrourus

Red-faced Mousebird Urocolius indicus

Alcedinidae: Kingfishers

Grey-headed Kingfisher Halcyon leucocephala

Woodland Kingfisher Halcyon senegalensis

Malachite Kingfisher Alcedo cristata

African Pigmy Kingfisher Ispidina picta

Meropidae: Bee Eaters

Little Bee eater Merops pusillius

Cinnamon-chested Bee eater Merops oreobates

European Bee eater Merops apiaster

Madagascar Bee eater Merops superciliosus

White-fronted Bee eater Merops bullockoides

Coraciidae: Rollers

Lilac-breasted Roller Coracias caudate

Rufous-crowned Roller Coracias naevia

Upupidae: Hoopoes

African Hoopoe Upupa africana

Phoenuculidae: Wood-hoopoes

Green Wood-hoopoe Phoeniculus purpureus 
Table 4. Continued

Bucerotidae: Hornbills

Red-billed Hornbill Tockus erythrorhynchus

Von der Decken's Hornbill Tockus deckeni

Jackson's Hornbill Tockus jacksoni

African Grey Hornbill Tockus nasutus

Captionidae: Barbets and Tinkerbirds

Red-fronted Tinkerbird Pogoniulus pusillus

Red-fronted Barbet Tricholaema diademata

Black-throated Barbet Tricholaema melanocephala

White-headed Barbet Lybius leucocephalus

d'Arnaud's Barbet Trachyphonus darnaudii

Red and yellow Barbet Trachyphonus erythrocephalus

Indicatoridae: Honeyguides:

Lesser Honeyguide Indicator minor

Picidae: Woodpeckers

Nubian Woodpecker Campethera nubica

Cardinal Woodpecker Dendropicos fuscescns

Bearded Woodpecker Dendropicos namaquus

Grey Woodpecker Dendropicos goertae

Alaudidae: Larks

Fischer's Sparrow-Lark Eremopterix leucopareia

Hirundinidae: Swallows and martins

Rock Martin Hirundo fuligula

Plain Martin Riparia paludicola

Sand Martin Riparia riparia

Red-rumped Swallow Hirundo daurica

Lesser Striped Swallow Hirundo abyssinica

Barn Swallow Hirundo rustica

Wire-tailed Swallow Hirundo smithii

Mosque Swallow Hiundo senegalensis

Motacillidae: Pipits and Wagtails

African Pied Wagtail Motacilla aguimp

Yellow-headed Wagtail Motacilla lutea

Yellow wagtail Motacilla flava

White wagtail Motacilla alba

Pycnonotidae: Bulbuls

Common Bulbul Pycnonotus barbatus

Turdidae: Thrushes

African Thrush Turdus pelios

Olive Thrush Turdus olivaceous

Spotted Morning Thrush Cichladusa guttata

White-browed Scrub Robin Cercotrichas guttata

Isabelline Wheatear Oenanthe isabellina

Pied Wheatear Oenanthe pleschanka

Northern Wheatear Oenanthe oenanthe

Sylvidae:Warblers

Olivaceous Warbler Hippolais pallida

Barred Warbler Sylvia nisoria

\section{Table 4. Continued}

Willow Warbler Phylloscopus trochilus

Yellow-breasted Apalis Apalis flavidus

Red-face Cromec Sylvieta whytii

Grey-backed Camaroptera Camaroptera brachyura

Muscicapidae: Flycatchers

Southern Black Flycatcher Melaenornis pammelaina

African Grey Flycatcher Bradornis microrhynchus

Spotted Flycatcher Muscicapa striata

Silverbird Empidornis semipartitus

Platysteiridae: Batises

Pygmy Batis Batis perkeo

Monarchidae: monarch flycatchers

African Paradise-flycatcher Terpsiphone viridis

Timaliidae: Chatterers and Babblers

Rufus Chatterer Turdoides rubiginosus

Northern Pied Babbler Turdoides hypoleucus

Paridae: Tits

White-bellied Tit Parus albiventris

Northern Grey Tit Parus thruppi

Red-throated Tit Parus fringillinus

Nectariniidae: Sunbirds

Beautiful Sunbird Cinnyris pulchella

Eastern Violet-backed Sunbird Anthreptes orientalis

Laniidae: Shrikes

Common Fiscal Lanius collaris

Long-tailed Fiscal Lanius cabanisi

Grey-backed Fiscal Lanius excubitoroides

Malaconotidae: Bush Shrikes

Tropical Boubou Laniarius aethiopicus

Slate-coloured Boubou Laniarius funebris

Brubru Nilaus afer

Black-backed Puffback Dryoscopus cubla

Northern Puffback Dryoscopus gambensis

Prionopidae: Helmet-shrikes

Northern White-crowned Shrike Eurocephalus rueppelli

Dicruridae: Drongos

Fork-tailed Drongo Dicrurus adsimilis

Corvidae: Crows

Pied Crow Corvus albus

Oriolidae: Orioles

African Black-headed Oriole Oriolus larvatus

African Golden Oriole Oriolus auratus

Sturnidae: Starlings and Oxpeckers

Rüppell's Long-tailed Starling Lamprotornis purpuropterus

Supurb Starling Lamprotornis superbus

Greater Blue-eared Starling Lamprotornis chalybaeus

Abbot's Starling Cinnyricinclus femoralis

Ashy Starling Cosmopsarus unicolor

Magpie Starling Speculipastor bicolour 
Table 4. Continued

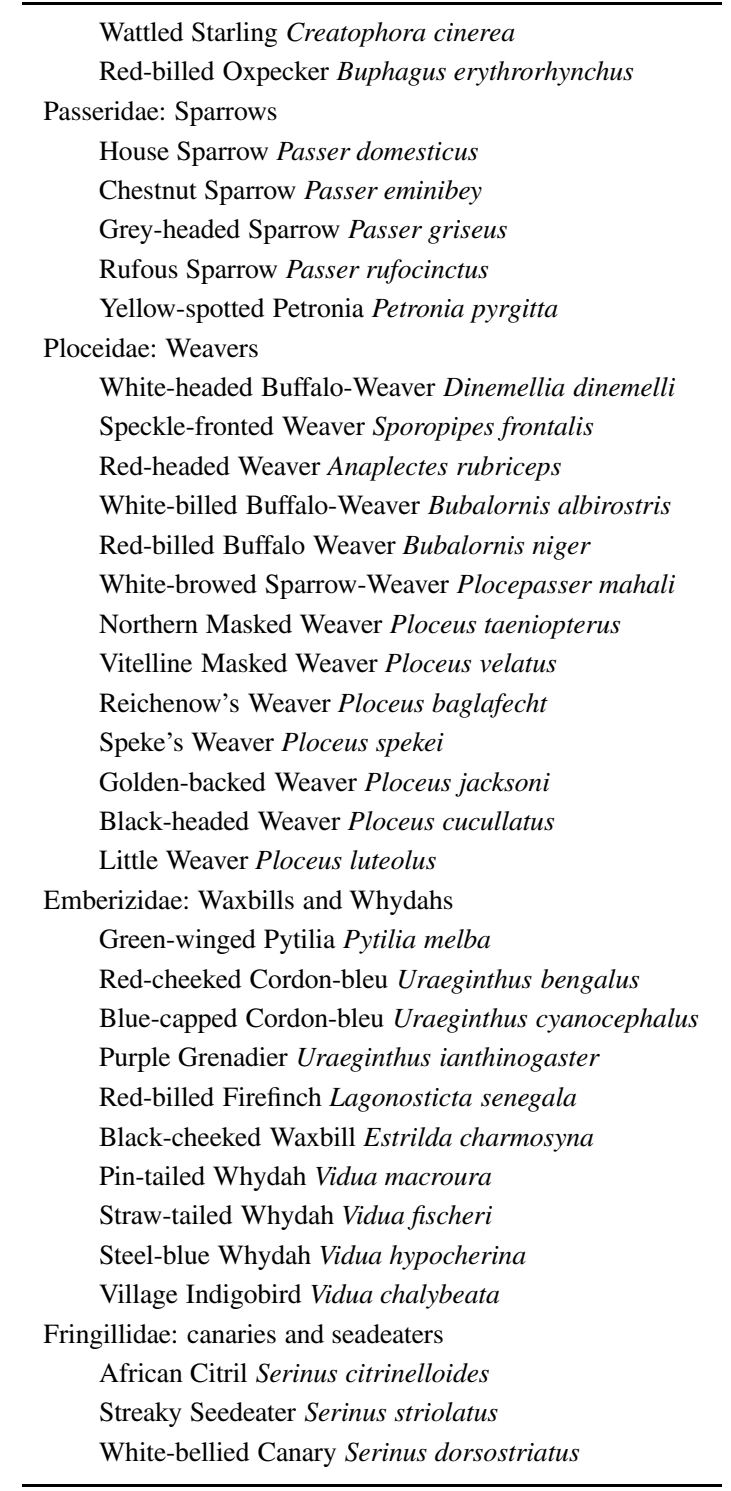

in Ethiopia such as Lake Aranguadi (Talling et al., 1973).

The monoculture of A. fusiformis in the phytoplankton, the absence of any macro-zooplankton, and a single species in the benthos, reflect the extreme saline environment. This implies instability, using the 'simple-unstable, diverse-stable' concept of ecology espoused in the 1970s. The initial data presented here however, indicates that a hydro-chemical stability confers an ecological stability on an extremely simple limnological food-web. The greatest instability in the lake was the outbreak of mortality of $P$. minor. Periodic large-scale die-offs have been reported for the past 40 years. Initially, these die-offs were attributed to starvation, due to sudden crashes of phytoplankton and other unknown causes (Brown, 1959). At Lake Nakuru, during the first three months of 1974, the $75 \%$ decline in the standing crop of A. fusiformis, was followed by a subsequent massive emigration of lesser flamingos from $>$ one million birds in January to < 10000 by August-September (Tuite, 2000). Amongst the approximately 10000 birds remaining during July and August, there was unusually high mortality, 420 carcasses being collected in 19 days (Sileo et al., 1979). In April, 51 debilitated birds (26 adults and 25 immature birds) were collected for analysis. Ten adults (38\%) and nine immature birds (36\%) had avian tuberculosis Mycobacterium avium Type 1 (Sileo et al., 1979). The rest perhaps were debilitated from a combination of starvation and the effects of parasites.

There have been three notable die-offs within the past decade, in 1993, 1995, and again in 19992000. The 1993 die-off, which was first noticed at Lake Bogoria and then a month later at Lake Nakuru, resulted in an estimated 18500 deaths on the two lakes. Zimbabwe veterinarians Nancy and Richard Kock studied this die-off, which occurred at a time when the population was unusually high, water levels declining, and ambient air temperatures high (Nasirwa \& Bennun, 1994; Kock et al., 1999). They concluded that the primary cause of death was "septicemia, complicated in those affected, by mycobacteriosis", or avian tuberculosis (Kock et al., 1999).

$M$. avium Type 1 was first isolated in a $P$. minor in Kenya at Lake Nakuru in 1970 by Koeman et al. (1972). The African fish eagle Haliaeetus vocifer feeds largely on P. minor there (Cooper et al., 1975) and in 1972, an $H$. vocifer at Lake Nakuru was also found infected with the disease (Kaliner \& Cooper, 1973). In 1973, Cooper et al. (1975) had found $M$. avium Type 1 in two of four debilitated $P$. minor also collected at Lake Nakuru. The species had been shown not to be very susceptible to avian TB in captive flocks held within avian collections where avian TB was otherwise prevalent (Wood, 1975), so it was not clear why they seemed so susceptible at Lake Nakuru, or how the disease was introduced there.

One hypothesis is that the bacterium might have been introduced to Lake Nakuru as an effect of ecological changes following the introduction of Tilapia grahami in the early 1960 s and the immigration of fish eating birds such as the pelican (Cooper et al., 
1975). Its spread to other lakes could then have been accomplished by the flamingos themselves through their constant vagrancy. In humans, susceptibility to tuberculosis increases amongst underweight and undernourished individuals living in overcrowded conditions (Evans \& Feldman, 1982; Benenson, 1990). Ratcliffe (1946) studied data from 3000 avian postmortems performed over a 20 -year period at the Philadelphia Zoological Garden and concluded that resistance of birds to tuberculosis was influenced by nutritional factors. Perhaps, the dense flocks of hungry P. minor at lakes Nakuru and Bogoria following a phytoplankton decline, provide the conditions for $M$. avium to become epizootic; at Bogoria the number of birds reached nearly a million just prior to each of the three mortalities (Owino et al., 2001). On the other hand, in some humans and laboratory animals, genetic factors have been shown to influence resistance to the disease (Evans \& Feldman, 1982). Wood (1975) suggested that similar factors might operate in flamingos, based on his observations of captive birds.

A second hypothesis to explain the mass lesser flamingo die-offs is that they are the result of toxicosis. A joint study by the World Wide Fund for Nature and Egerton University found substantial amounts of hepatoxic algae and toxic metals, particularly chromium, in Lake Nakuru that appears to have originated from industries surrounding the lake. Web-site claims were made for high levels in bird tissues although these have not yet been supported by scientific publication. A linked experimental study predicted increased metal exposure rates through increased absorption by birds as the population of A. fusiformis declined (Nelson et al., 1998), which provided a possible explanation for the die-offs observed at Lake Nakuru. Toxicosis is not yet clearly a cause of flamingo deaths at Lake Nakuru without hard evidence, but cannot be ruled out. In Lake Bogoria however, where the 1993 dieoff was first noticed and the 1999-2000 was almost entirely confined, there is no polluting industry in its catchment.

The pathological role of algal toxins in flamingos has also been suggested as a contributing factor at Bogoria (Krienitz et al., 2003), where toxin-secreting species were identified in hot-spring streams and in two flamingo carcasses in 2001, the period of the lower mortality-peak (see above). In greater flamingos, cyanobacterial toxins from planktonic species known to be toxin-generating - Microcystis aeruginosa and Anabaena flos-aquae - have been identified as the causative agents for a mortality of $60 \%$ of Phoenicopterus ruber chicks in Doñana National Park, southern Spain, in 2001. At Bogoria, the water of hot spring streams is potable if its salinity is substantially lower than lake water (conductivity by up to one-third lower, pers. obs. DMH). Lines of birds may be seen drinking from such streams (e.g. Fig. 1E in Krienitz et al., 2003). However, the water represents a small proportion of the available drinking water at Bogoria and hot spring sources are primarily located along the middle of the western shore. In the north, the Sandai river brings a small permanent flow of the diverted Loboi river and in the south, two freshwater springs supply permanent streams; all three are used extensively for drinking (DMH, RBC, MMH, pers. obs.).

In all probability there are multiple causes of the mortality. Avian tuberculosis may be endemic in the population but not lethal to individuals unless their immunity has been compromised by another factor. It is perhaps not an accident that all three mortalities in the 1990s occurred towards the end of long droughts (LaVigne \& Ashley, 2001) as well as at a time when the number of birds at Bogoria peaked at close to 1 $\times 10^{6}$ (Owino et al., 2001), both factors which would have increased stress on individuals. The population in 2000 might also have been undernourished, since the quantity of A. fusiformis was low and the filtering demands of P. minor are high (Vareschi, 1978).

\section{Acknowledgements}

This project was funded from 2000-3 by the Earthwatch Institute and the first 8 authors acknowledge the assistance of numerous Earthwatch volunteers in all aspects of the work. WM acknowledges the British Council for the funding of her work 1988-9. The work was made possible in the field by permission and assistance of William Kimosop, LBNR Head Warden and by research permission from the Government of Kenya, with the logistical support of Dr Leon Bennun (Ornithology Department, National Museums of Kenya) and Professor Kenneth Mavuti (Department of Zoology, University of Nairobi). Dr Wanja Kinuthia, Head of the Entomology Dept at The National Museum of Kenya gave valuable access to the national collection. The logistics of maintaining a camp in the arid north-Kenyan environment was managed superbly by Mrs Velia Carn and her staff, whilst our Kenyan research assistants James Njoroge and Reuben Ngete were invaluable and dependable. 


\section{References}

Agnew, A. D. Q. \& S. Agnew, 1994. Upland Kenya Wild Flowers: A Flora of the Ferns and Herbaceous Flowering Plants of Upland Kenya. 2nd edn. East Africa Natural History Society, Nairobi.

Alonso-Andicoberry, L. Garcia-Villada, V. Lopez-Rodas \& E. Costas, 2002. Catastrophic mortality of flamingos in a Spanish national park caused by cyanobacteria. The Vetinary Record 151: 706-707.

Anon, 2003. Death of a lake: Lake Nakuru's disappearing catchment. Ecoforum Short Rains: 14-15.

Bartholomew, G. A. \& C. J. Pennycuick, 1973. The flamingo and pelican populations of the Rift Valley lakes in 1968-69. East African Wildlife J. 11: 189-198.

Beadle, L. C., 1981. The Inland Waters of Tropical Africa, 2nd edn. Longman: $475 \mathrm{pp}$.

Benenson, A. S. (ed.), 1990. Control of Communicable Diseases in Man. 15th edition. Washington DC: American Public Health Association.

Bennun, L. A. \& O. Nasirwa, 2000. Trends in waterbird numbers in southern Rift Valley of Kenya. Ostrich 71: 220-226.

Bennun, L. \& P. Ngoroge, 1999. Important Bird Areas in Kenya. Nairobi: Nature Kenya; The East Africa Natural History Society.

Brown, L. H., 1959. The Mystery of the Flamingos, London: Country Life Ltd. 116 pp.

Brown, L., 1979. Encounters with Nature. Chapter 6; Flamingos. Oxford University Press, Oxford: 67-89.

Brown, L. H. \& P. L. Britton, 1980. The Breeding Seasons of East African Birds. Nairobi: The East Africa Natural History Society.

Brown, L. H. \& A. Root, 1971. The breeding behaviour of the lesser flamingo Phoeniconaias minor. Ibis 113: 147-172.

Chalié, F. \& F. Gasse, 2002. Late glacial-holocene diatom record of water chemistry and lake level change from the tropical East African Rift lake Abiyata (Ethiopia). Palaeogeography, Palaeoclimatology, Palaeoecology 187: 259-283.

Constanza R., R. d'Arge, R. de Groot, S. Farber, M. Grasso, B. Hannon, K. Limburg, S. Naeem, R. V. O’Neill, J. Paruelo, R. G. Raskin, P. Sutton \& M. van den Belt, 1997. The value of the worlds' ecosystem services and natural capital. Nature 387: 253260.

Cooper, J. E., L. Karstad \& E. Boughton, 1975. Tuberculosis in Lesser Flamingos in Kenya. J. Wildlife Diseases 11: 32-36.

Davies, T. D., C. E. Vincent \& A. K. C. Beresford, 1985. JulyAugust rainfall in west-central Kenya. J. Climatol. 5: 17-33.

Duckworth, A. W., W. D. Grant, B. E. Jones \& R. van Steenbergen, 1996. Phylogenetic diversity of soda lake alkliphiles. FEMS Microbiol. Ecol. 19: 181-191.

Escuté-Gasulla X., M. M. Pérez, L. F. Gonzålez-Solis \& M.G. Süné, 2002. The Lesser Flamingo Expedition Kenya 2000-2001. Unpublished Report, University of Barcelona.

Evans, A. S. \& H. A. Feldman, 1982. Bacterial Infections of Humans: Epidemiology and Control. London: Plenum Medical Book Company.

Gasse, F., 1986. East African Diatoms. Taxonomy, Ecological Distribution. Bibliotheca Diatomologica. Bd 11, J. Cramer, Stuttgart. $202 \mathrm{pp}$

Grant, W. D., W. E. Mwatha \& B. E. Jones, 1990. Alkaliphiles: ecology, diversity and applications. FEMS Microbiol. Rev. 75: 255-270.

Gough, D., 2000. No haven as disease claims lives of 30000 flamingos. The Guardian, 6 March 2000: 16.

Haines, R. W. \& K. A. Lye, 1983. The Sedges and Rushes of East Africa. East Africa Natural History Society, Nairobi, Kenya.
Harper J. L. \& D. L. Hawksworth, 1994. Biodiversity: measurement and evaluation. Phil. Trans. r. Soc. Lond. B. 345: 5-12.

Hilton-Taylor, C. (eds), 2000. IUCN Red List of Threatened Species. International Union for the Conservation of Nature, Gland, Switzerland. $61 \mathrm{pp}$

Hindák, F., 1985. Morphology of trichomes in Spirulina fusiformis Voronichin from Lake Bogoria Kenya. Arch. Hydrobiol. Suppl. Algol Std. 38/9: 201-218.

Jellison, R., A. Adams \& J.M. Melack 2001. Re-appearance of rotifers in hypersaline Mono Lake, California, during a period of rising lake levels and decreasing salinity. Hydrobiologia 466: $39-43$.

Jenkin, P. M., 1936. Reports on the Percy Sladen Expedition to some Rift Valley Lakes in Kenya in 1929 VII. Summary of the ecological results with special reference to the alkaline lakes. Ann. Mag. Nat. Hist. Ser. 10, 18: 133-181.

Jones, B. E., W. D. Grant, N. C. Colins \& W. E. Mwatha, 1994. Alkaliphiles: diversity and identification. In Priest, F. G., A. Ramos-Cormenzana \& B. J. Tindall (eds), Bacterial Diversity and Systematics. Plenum Press: 195-229.

Kaliner, G. \& J. E. Cooper, 1973. Dual infection of an African Fish Eagle with acid-fast bacilli and an Aspergillus sp. J. Wildlife Diseases 9: 51-55.

Kock, N. D., R. A. Kock, J. Wambua, G. J. Kamau \& K. Mohan, 1999. Mycobacterium avium-related epizootic in free-ranging lesser flamingos in Kenya. J. Wildlife Diseases 35: 297-300.

Koeman, J. H., J. H. Pennings, J. J. M. de Goeij, P. S. Tjioe, P. M. Olindo \& J. Hopcraft, 1972. A preliminary survey of the possible contamination of Lake Nakuru in Kenya with some metals and chlorinated hydrocarbon pesticides. J. appl. Ecol. 9: 411-416.

Krienitz, L., A. Ballot, K. Kotut, C. Weigand, S. Putz, J. S. Metcalf, G. A. Codd \& S. Pflugmacher, 2003. Contribution of hot spring cyanobacteria to the mysterious deaths of Lesser Flamingos at Lake Bogoria, Kenya. FEMS Microbiol. Ecol. 43: 141-148.

LaVigne, M. \& G. Ashley, 2001. Climatology and Rainfall Patterns: Lake Bogoria National Reserve (1976-2001). Unpublished thesis, New Hampshire College, Amherst MA, U.S.A. 32 pp + appendix.

Legesse, D., F. Gasse, O. Radakovitch, C. Vallet-Culomb, R. Bonnefille, D. Verschuren, E. Gibert \& P. Barker 2002. Environmental changes in a tropical lake (Lake Abiyata, Ethiopia) during recent centuries. Palaeogeography, Palaeoclimatology, Palaeoecology 187: 233-258.

Livingstone, D. A. \& J. M. Melack, 1984. Some lakes of subSaharan Africa. In Taub, F. B. (ed.), Ecosystems of the World 23, Lakes and Reservoirs. Elsevier, Amsterdam: 467-498.

Melack, J. M., R. Jellison \& D. B. Herbst (eds), 2001. Seventh International Conference on Salt Lakes (September 1999). Hydrobiologia 466: 1-347.

Melack J. M. \& P. Kilham, 1974. Photosynthetic rates of phytoplankton in East African alkaline, saline lakes. Limnol. Oceanogr. 19: 743-755.

Melack, J. M., 1981. Photosynthetic activity of phytoplankton in tropical African soda lakes. Hydrobiologia 81: 71-85.

Melack, J. M., 1988, Primary producer dynamics associated with evaporative concentration in a shallow, equatorial soda lake (Lake Elmenteita, Kenya). Hydrobiologia 158: 1-14.

McCullough G., A. Aebischer \& K. Irvine, 2003. Importance of small wetlands for migrations of African flamingos. Oryx, in press.

Nasirwa, 2000. Conservation statusd of flamingos in Kenya. Waterbirds 23 (Special Publication 1): 47-51. 
Nasirwa, O. \& L. A. Bennun, 1994. Waterbirds in the southern Kenyan Rift Valley, July 1993 and January 1994. Nairobi: The National Museums of Kenya.

Nelson, Y. M., R. J. Thampy, G. K. Motelin, J. A. Raini, C. I. Difante \& L. Wilson, 1998. Model for trace metal exposure in filter-feeding flamingos at alkaline Rift Valley lakes, Kenya. Environmental Toxicology and Chemistry 17: 2302-2309.

Nilsson, E., 1932. Quarternary glaciations and pluvial lakes in British East Africa. Ph.D. Thesis, Centraltryckeriet, Stockholm:101+ 4 plates.

Onkware, A. O., 1996. The Ecophysiology of Grass and Sedge Halophytes of Loburu Delta, Lake Bogoria National Reserve, Kenya. Unpublished thesis, Moi University, Kenya.

Owino, A., J. O. Oyugi, O. O. Nasirwa \& L. A. Bennun, 2001. Patterns of variation in waterbird numbers on four Rift Valley lakes in Kenya. Hydrobiologia 458: 45-53.

Ratcliffe, H. L., 1946. Tuberculosis in captive wild birds. Am. Rev. Tuberculosis 54: 389-400.

Sileo, L., J. G. Grootenhuis, C. H. Tuite \& J. B. D. Hopcraft, 1979. Mycobacteriosis in the Lesser Flamingos of Lake Nakuru, Kenya. J. Wildlife Diseases 15: 387-389.

Simmons, R. E., 2000. Declines and movements of lesser flamingos in Africa. Waterbirds 23 (Special Publication 1): 40-46.

Stephen, T. \& J. Fanshawe, 2002. Field Guide to the Birds of East Africa. T \& A. D. Poyser, London: 603 pp.

Talling, J. F. \& D. Driver, 1963. Some problems in the estimation of chlorophyll-a in phytoplankton. Proc. Conference of Primary Productivity Measurement, marine and Freshwater, Hawaii, 1961. U.S. Atomic Energy Comm., TID-7633: 142-146.

Talling, J. F. \& I. B. Talling, 1965. The chemical composition of African lake waters. Int. Rev. ges. Hydrobiol. 50: 421-463.

Talling, J. F., R. B. Wood, M. V. Prosser \& R. M. Baxter, 1973. The upper limit of photosynthetic productivity by phytoplankton: evidence from Ethiopian soda lakes. Freshwat. Biol. 3: 53-76.

Tuite, C. H., 1979. Population size, distribution, and biomass density of the lesser flamingo in the eastern Rift Valley, 1974-76. J. appl. Ecol. 16: 765-775.

Tuite, C. H., 2000. The distribution and density of Lesser Flamingos in East Africa in relation to food availability and productivity. Waterbirds 23 (Special Publication 1): 52-63.
Vareschi, E., 1978. The ecology of Lake Nakuru (Kenya) I. Abundance and feeding of the lesser flamingo. Oecologia (berl.) 32: 11-35.

Vareschi, E., 1982. The ecology of Lake Nakuru (Kenya) III. Abiotic factors and primary production. Oecologia 55: 81-101.

Vareschi, E., 1987. Saline lake ecosystems. In Schulze, E.-D. \& H. Zwolfer (eds), Potentials and Limitations of Ecosystem Analysis. Springer-Verlag, Berlin: 347-363.

Verschuren, D., C. Cocquyt, J. Tibby, C. N. Roberts \& P. R. Leavitt, 1999. Long-term dynamics of algal and invertebrate communities in a small, fluctuating, tropical soda lake. Limnol. Oceanogr. 44: 1216-1231.

Vosmarty, C. J., P. Green, J. Salisbury \& R. B. Lammers, 2000. Global water resources: vulnerability from climate change and population growth. Science 289: 284-288.

Wilcox, B. A., 1984. In situ conservation of genetic resources: determinants of minimum area requirements. In Neeley, J. A. \& K. R. Miller (eds), National Parks: Conservation and Development. Smithsonian Institution Press, Washington DC: 639-647.

Weiss, E., 1989. Guide to Plants Tolerant of Arid and Semiarid Conditions: Nomenclature and Potential Uses. Margraf Scientific Publications, Germany/Ministry of Livestock Development, Kenya.

Williams, J. G., 1967. A Field Guide to the National Parks of East Africa. Collins: $352 \mathrm{pp}$.

Wilson. E. O., (ed.), 1987. Technologies to Maintain Biological Diversity. US Office of Technology Assessment, Washington.

Wilson, E. O. (ed.), 1988. BioDiversity. National Academy Press, Washington DC.

Wilson, E. O., 2002. The Future of Life. Little, Brown. 230 pp.

Wood, N. A., 1975. Tuberculosis. In Kear, J. \& N. Duplaix-Hall (eds), Flamingos. T. \& A. D. Poyser, Berkhamsted, England: 205-207.

Wood, R. B. \& J. F. Talling, 1988. Chemical and algal relationships in a salinity series of Ethiopian inland waters. Hydrobiologia 158: 29-67. 